DOI: $10.19195 / 0524-4544.323 .9$

\author{
ANDRZEJ PAKUŁA \\ Uniwersytet Wrocławski \\ e-mail: andrzej.pakula@uwr.edu.pl
}

\title{
Zasada racjonalności w zjawisku administracji publicznej w kontekście tzw. prywatyzacji zadań publicznych
}

\section{Uwagi wstępne - zjawisko administracji publicznej}

W demokratycznym państwie prawnym administracja publiczna ujmowana jest w pierwszej kolejności w kategoriach prawno-ustrojowych jako obszar władzy wykonawczej, posiadającej swoją dziedzinę kompetencyjną oraz pozostającej w stosownych relacjach do pozostałych dwóch obszarów władzy publicznej, tj. władzy ustawodawczej i władzy sądowniczej. Nie wyklucza to możliwości innych ujęć, takich chociażby jak propozycja Jerzego Stefana Langroda czy przede wszystkim - Franciszka Longchampsa.

Zdaniem pierwszego z przywołanych, bez wątpienia klasyków administratywistyki:

Administracja [...] to ludzie zorganizowani po to, aby korzystając z przydzielonej im dziedziny aktywności (sfery działania) i z rozporządzalnych rzeczy (środków działania), mogli spełniać swoje zadanie. Czy ujmiemy ich łącznie w ramy teoretyczne konstrukcji służby publicznej, czy inaczej, zawsze będzie to przede wszystkim planowe zgrupowanie ludzi w służbie pewnej misji publicznej, a dopiero potem — poprzez tych ludzi — suma urządzeń, którymi oni dysponują ${ }^{1}$.

Nie ulega wątpliwości, że w przytoczonym stanowisku zawiera się, aczkolwiek nie wprost, istota administracji publicznej jako szczególnego rodzaju aktywności człowieka. Aspekt ten w sposób jednoznaczny akcentuje w swoim sta-

1 J.S. Langrod, Instytucje prawa administracyjnego. Zarys części ogólnej, Kraków 2003, s. 228 . 
nowisku F. Longchamps, ujmując administrację publiczną jako zjawisko i jako układ $^{2}$, przy czym zasadniczą rolę odgrywa zjawisko administracji publicznej. Autor określa je jako działanie kulturowe, podejmowane (zachodzące, odbywające się) na stanowisku publicznym, objęte podziałem pracy ${ }^{3}$. Samo zaś działanie kulturowe to w jego rozumieniu ,działanie człowieka, które wprowadza zmianę w rzeczywistości i dla którego daje się oznaczyć jakiś stosunek do jakiejś wartości”4. Wartości to z kolei „obiektywy społeczne, które występują we współżyciu społecznym jako podstawy ocen”, same zaś „,[o]biektywy społeczne są to takie treści pomyślane, które są we współżyciu traktowane przez innych ludzi jako zewnętrzne i choć w części niezależne od ich własnych przeżyć"6.

Uzupełniając koncepcję F. Longchampsa odnośnie do samego rozumienia działania, godzi się wskazać przynajmniej dwa ujęcia tego problemu: socjologiczne i prakseologiczne.

Działanie w rozumieniu socjologicznym to - w definicji Piotra Sztompki ,[z]achowanie wyposażone w znaczenie, sens [...], zachowanie, z którym związane jest znaczenie motywacyjne i kulturowe”, zachowanie zaś to „zewnetrznie obserwowalny ruch fizyczny przejawiany przez ludzi" "․ Nie ulega wątpliwości, że sens, czy też znaczenie motywacyjne i kulturowe, można interpretować w kategorii celowości działania.

Jednoznacznie i zarazem zdecydowanie pełniej istotę działania ujmuje prakseologia. Jan Zieleniewski, uczeń Tadeusza Kotarbińskiego — twórcy prakseologii, stwierdza, że

działa organizm żywy, a w szczególności czlowiek, gdy zmierza dowolnie do wywołania jakichś, uznanych przez siebie za pożądane, zmian stanów rzeczy lub do utrzymania takich stanów bez zmiany. [...] Działanie w znaczeniu prakseologicznym możemy więc określić jako zachowanie się umyślne, zmierzające do celu ${ }^{8}$.

W literaturze przedmiotu przyjmuje się ostatecznie, że w ujęciu prakseologicznym działanie to „dowolne zachowanie umyślne, podejmowane świadomie lub podświadomie dla osiągnięcia określonego celu"9.

${ }^{2}$ F. Longchamps, Założenia nauki administracji, Wrocław 1993, s. 89.

3 Ibidem, s. 87.

4 Ibidem, s. 74. Głęboką analizę działań administracji publicznej zawiera praca M. Stefaniuka, Działanie administracji publicznej w ujęciu nauk administracyjnych, Lublin 2009.

${ }^{5}$ F. Longchamps, op. cit., s. 76.

6 Ibidem.

7 P. Sztompka, Socjologia. Analiza spoleczeństwa, Kraków 2005, s. 48, 64-65.

8 J. Zieleniewski, Organizacja zespołów ludzkich. Wstęp do teorii organizacji i kierowania, Warszawa 1972, s. 183.

9 J. Korczak, Działanie i cel, [w:] A. Chrisidu-Budnik et al., Nauka organizacji i zarzadzania, Wrocław 2005, s. 129. 


\section{Racjonalność i jej rodzaje}

Należy zauważyć, że każde działanie i jego skutki, także jako treść zjawiska administracji publicznej, podlega osądowi, ocenie. Jedną z takich kategorii ocennych — w terminologii F. Longchampsa: obiektywem społecznym — jest racjonalność.

W ujęciu słownikowym ,racjonalny to rozumny; oparty na zasadach poprawnego myślenia i skutecznego działania; uzasadniony; wyrozumowany"10. W socjologicznym rozumieniu racjonalność to ,apoteoza rozumu, rozwagi, kalkulacji, obiektywności, efektywności. Dotyczy to przede wszystkim funkcjonowania or-

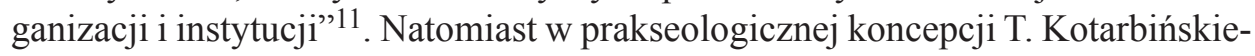
go racjonalność odnoszona jest do każdego działania i oznacza, że

[i]m zaś lepiej jest działanie przystosowane do okoliczności i w ogóle do wszystkiego, cokolwiek w sądzie prawdziwym stwierdzić można, tym bardziej jest ono racjonalne. [...] Tu z kolei wypadnie dokonać rozróżnienia i przeciwstawić racjonalność w sensie rzeczowym racjonalności w sensie metodologicznym. Gdy mówiło się przed chwilą o racjonalności jako przystosowaniu do prawdy, mówiło się o racjonalności w sensie rzeczowym. Natomiast sens metodologiczny mamy na myśli, ilekroć uznajemy za rozumne, czyli racjonalne, postępowanie danego osobnika, skoro postępuje on wedle wskazań posiadanej wiedzy, a przez posiadaną wiedzę rozumiemy tutaj ogół tych posiadanych informacji, którym, zważywszy na sposób ich uzasadnienia, ów osobnik winien przypisać prawdopodobieństwo dostateczne do tego, by postępować tak, jak gdyby były prawdziwe ${ }^{12}$.

Takie ujmowanie racjonalności można uznać za najbardziej popularne. Wydaje się jednak, że na potrzeby analizy zjawiska administracji publicznej jako działania warto skorzystać z innej koncepcji rozumienia racjonalności, zaproponowanej przez twórcę akademickiej socjologii niemieckiej, lecz także ekonomistę, religioznawcę, historyka myśli społecznej i wreszcie prawnika — Maxa Webera. Autor ten wprowadził m.in. pojęcie działania społecznego. W jego rozumieniu

[d]ziałanie społeczne (w tym także zaniechanie i znoszenie) może orientować się na przeszłe, obecne lub oczekiwane w przyszłości zachowania innych ludzi [...]. Owi inni oznaczać mogą jednostki, i to znane, albo też nieokreśloną wielość całkiem nieznanych ludzi $[\ldots]^{13}$.

\section{Weber podkreśla przy tym, że}

[n]ie każdy rodzaj styczności ludzi ma charakter społeczny, lecz wyłącznie zachowanie z punktu widzenia sensu zorientowane na zachowanie innego człowieka ${ }^{14}$.

W ujęciu P. Sztompki oznacza to takie działania, „,w których uwzględnia się aktualne lub potencjalne reakcje innych i według tego kształtuje się przebieg własnego działania"15.

\footnotetext{
10 W. Kopaliński, Stownik wyrazów obcych i zwrotów obcojęzycznych, Warszawa 1983, s. 355.

11 P. Sztompka, op. cit., s. 564.

12 T. Kotarbiński, Traktat o dobrej robocie, Wrocław-Warszawa-Kraków 1975, s. 123-124.

13 M. Weber, Gospodarka i społeczeństwo. Zarys socjologii rozumiejącej, Warszawa 2002, s. 17.

14 Ibidem.

15 P. Sztompka, op. cit., s. 59.
} 
Tak rozumiane działanie społeczne może, zdaniem M. Webera, przejawiać się w czterech postaciach, mianowicie działaniach:

1) celoworacjonalnych,

2) wartościoworacjonalnych,

3) afektywnych, w szczególności emocjonalnych,

4) tradycjonalnych ${ }^{16}$.

Przedmiot niniejszego opracowania, siłą rzeczy, kieruje uwagę ku dwóm pierwszym kategoriom.

Odnośnie do pierwszej z nich M. Weber stwierdza, że

[c]eloworacjonalnie działa ten, kto orientuje swe działanie na cel, środki i skutki uboczne oraz rozważa przy tym racjonalnie zarówno środki w odniesieniu do celów, jak i cele w odniesieniu do skutków ubocznych, podobnie jak różne możliwe cele, a zatem w każdym razie nie działa w sposób ani afektywny (szczególnie emocjonalny), ani tradycjonalny. Rozstrzygnięcie między konkurującymi i kolidującymi celami i następstwami może mieć charakter wartościowo racjonalny, wtedy działanie jest celowo racjonalne, tylko gdy idzie o jego środki ${ }^{17}$.

Jest to zatem kalkulacja przeddecyzyjna, porównywanie spodziewanych korzyści do kosztów, jakie należałoby ponieść dla ich osiągnięcia, potocznie określana opłacalnością ${ }^{18}$.

Wartościoworacjonalne działanie występuje natomiast,

gdy ktoś, bez względu na dające się przewidzieć następstwa, działa w myśl swego przekonania o tym, co nakazuje obowiązek, godność, piękno, religijne wskazanie, cześć, czy też doniosłość jakiejś sprawy, jakiegokolwiek rodzaju. Działanie wartościowo racjonalne jest zawsze (w naszej terminologii) działaniem wedle przykazań lub wymagań, które działający uważa za wiążące. Tylko o ile ludzkie działanie orientuje się na takie wymagania — co jednak ma miejsce wyłącznie w pewnym, bardzo różnym, zwykle dość ograniczonym zakresie — możemy mówić o racjonalności w odniesieniu do wartości ${ }^{19}$.

\section{Zjawisko administracji publicznej jako działanie społeczne}

W demokratycznym państwie prawnym zjawisko administracji publicznej to bez wątpienia działania społeczne, których treścią jest wykonywanie określonych prawem zadań publicznych. Zakres tych zadań był początkowo - w pierwszym okresie kształtowania się państwa prawnego - ograniczony w zasadzie

16 M. Weber, op. cit., s. 18-19.

17 Ibidem, s. 19.

18 P. Sztompka ten rodzaj racjonalności określa mianem „instrumentalnej”-idem, op. cit., s. 59,65 .

19 M. Weber, op. cit., s. 19. P. Sztompka ten rodzaj racjonalności nazywa „autoteliczną”. Nie można jednak zgodzić się z jego uwagą, że oznacza to postępowanie według formuły „cel uświęca środki”-idem, op. cit., s. 59, 65. 
do podstawowych kwestii ochrony porządku i bezpieczeństwa publicznego oraz ochrony wolnokonkurencyjnej gospodarki kapitalistycznej (chociaż uznawano potrzebę prowadzenia przez państwo pełnej działalności uzupełniającej, jednakże niekoniecznie w sferze socjalnej) ${ }^{20}$. Z czasem, pod wpływem m.in. skutków obu wojen światowych i kryzysu ekonomicznego lat trzydziestych, rozszerzył się o dziedziny pozostawione dotychczas zasadniczo inicjatywie samych obywateli, które ogólnie można określić mianem usług publicznych, które za Tadeuszem Kutą można by ująć jako

rozmaitego rodzaju korzyści (materialne lub niematerialne), które administracja daje na rzecz ogółu, czy to w postaci bezpośredniej (świadczenia usług), czy też pośrednio przez stwarzanie warunków do świadczenia usług (działania organizujące) ${ }^{21}$,

z wyłączeniem produkcji dóbr (towarów).

Administracja publiczna przejmuje na siebie ciężar zaspokajania takich potrzeb, jak oświatowe, komunikacyjne, transportowe, kulturalne, zdrowotne, bytowe, opiekuńcze oraz odpowiedzialność za poziom ich realizacji. Następuje rozbudowa struktur administracji publicznej o nowe kategorie podmiotów administrujących, niebędących klasycznymi organami, aczkolwiek działających w reżimie prawa administracyjnego. Podmiotami tymi są przedsiębiorstwa użyteczności publicznej oraz zakłady administracyjne, tworzone i podporządkowane stosownym organom administracji publicznej, przy czym te pierwsze obejmują obszar usług materialnych (m.in. dostarczanie energii, ciepła, gospodarka wodno-ściekowa, gospodarka odpadami, transport zbiorowy, łączność), podczas gdy drugie obejmują obszar usług niematerialnych (m.in. oświata, kultura, ochrona zdrowia, pomoc społeczna, szkolnictwo wyższe, rekreacja).

Hubert Izdebski i Michał Kulesza w kontekście omawiania funkcji współczesnej administracji publicznej wskazują podstawowy problem administracji świadczącej (administracji usług), którym jest

wielka liczba odbiorców usług, a zatem jeśli sama [administracja - A.P.] świadczy usługi, potrzeba dysponowania ogromnym potencjałem tak rzeczowym, jak i kadrowym, służącym realizacji jej celów 22 .

Pojawia się zatem istotny problem natury pragmatyycznej. Stanisław Biernat zwraca uwagę, że

okazuje się coraz częściej, że wykonywnie zadań przez państwo w obecnym [dotyczy to lat osiemdziesiątych i dziewięćdziesiątych ubiegłego stulecia, lecz także dziś jest to aktualne - A.P.] rozmiarze, różnorodności i w dotychczasowych formach organizacyjnych staje się trudniejsze, a niekiedy — wręcz niemożliwe. Wynika to, z jednej strony, z ograniczonych możliwości materialnych,

20 Tak: Z. Leoński, Nauka administracji, Warszawa 2002, s. 29.

21 T. Kuta, Aspekty prawne działań administracji publicznej w organizowaniu ustug, Wrocław 1969, s. 27.

22 H. Izdebski, M. Kulesza, Administracja publiczna. Zagadnienia ogólne, Warszawa 2004, s. 111 . 
kadrowych, poziomu wymaganych kwalifikacji i wyposażenia technicznego administracji publicznej, a z drugiej strony, z rosnących wymagań obywateli ${ }^{23}$.

Pojawiają się koncepcje postulujące weryfikację dotychczasowych poglądów na temat roli administracji publicznej w życiu społecznym i gospodarczym, zakresu zadań publicznych i form ich realizacji. Jednym z postulowanych rozwiązań jest stworzenie możliwości powierzania realizacji zadań publicznych podmiotom niepublicznym. W Polsce podstawową regulację w tej mierze zawiera Ustawa z dnia 24 kwienia 2003 r. o działalności pożytku publicznego i o wolontariacie ${ }^{24}$.

\section{Powierzanie realizacji zadań publicznych}

W myśl regulacji zawartej w art. 5 ust. 2 pkt 1 ustawy organy administracji publicznej mogą zlecać uprawnionym podmiotom realizację zadań publicznych. Podmiotami uprawnionymi są, stosownie do treści art. 3 ust. 1 i 3 ustawy, organizacje pozarządowe oraz osoby prawne i jednostki organizacyjne Kościołów i związków wyznaniowych, stowarzyszenia jednostek samorządu terytorialnego, spółdzielnie socjalne, spółki akcyjne i spółki z ograniczoną odpowiedzialnocią oraz kluby sportowe działające na podstawie ustawy o sporcie, które nie działają w celu osiągnięcia zysku oraz przeznaczają całość dochodu na realizację celów statutowych i nie przeznaczają zysku do podziału między swoich udziałowców, akcjonariuszy i pracowników.

Zakres zadań publicznych o charakterze społecznie użytecznym obejmuje, zgodnie z treścią art. 4 ustawy, 37 obszarów zadaniowych, m.in. w zakresie pomocy społecznej, ochrony i promocji zdrowia, promocji zatrudnienia i aktywizacji zawodowej, nauki, szkolnictwa wyższego, edukacji, oświaty i wychowania, kultury, sztuki, ochrony dóbr kultury i dziedzictwa narodowego, wspierania i upowszechniania kultury fizycznej, porządku i bezpieczeństwa publicznego, obronności państwa i działalności Sił Zbrojnych Rzeczypospolitej Polskiej, ratownictwa i ochrony ludności, działalności na rzecz kombatantów i osób represjonowanych, działalności na rzecz rodziny, macierzyństwa, rodzicielstwa, upowszechnianiania i ochrony praw dziecka, przeciwdziałania uzależnieniom i patologiom społecznym.

Ustawa, w art. 11 ust. 1, przewiduje dwie formy zlecania, mianowicie wspieranie podmiotów uprawnionych, prowadzących już działalność w sferze zadań określonych $\mathrm{w}$ ustawie, oraz powierzanie zadań podmiotom uprawnionym do realizacji zadań publicznych określonych w ustawie. W obu wypadkach ustawa wymaga stosownej procedury konkursowej.

23 S. Biernat, Prywatyzacja zadań publicznych. Problematyka prawna, Warszawa-Kraków 1994, s. 8.

24 Tekst jedn. Dz.U. z 2016 r. poz. 1817; dalej: ustawa. 
Z inicjatywą realizacji zadania publicznego w trybie ustawy może wystąpić zarówno zainteresowany podmiot uprawniony, jak i organ administracji publicznej.

W pierwszym przypadku, stosownie do art. 12 ust. 1 ustawy, zainteresowany podmiot uprawniony składa wniosek o realizację zadania publicznego, który powinien zawierać opis zadania publicznego oraz szacunkową kalkulację kosztów jego realizacji.

W drugim natomiast, w myśl art. 13 ustawy, organ administracji publicznej ogłasza otwarty konkurs ofert. Ogłoszenie powinno zawierać informacje o rodzaju zadania, wysokości środków publicznych przeznaczonych na jego realizację, zasadach przyznawania dotacji, terminach i warunkach realizacji zadania, terminie składania ofert oraz trybie i kryteriach stosowanych przy wyborze ofert i terminie dokonania wyboru, a także o zrealizowanych przez organ administracji publicznej w roku ogłoszenia otwartego konkursu ofert i w roku poprzednim zadaniach publicznych tego samego rodzaju i związanych z nimi kosztami, ze szczególnym uwzględnieniem wysokości dotacji przekazanych podmiotom uprawnionym. Ogłoszenie zamieszcza się w Biuletynie Informacji Publicznej, w siedzibie organu administracji publicznej w miejscu przeznaczonym na zamieszaczanie ogłoszeń oraz na stronie internetowej organu.

Zainteresowany podmiot uprawniony, stosownie do regulacji zawartej w art. 14 ust. 1 ustawy, powinien podać w ofercie szczegółowy zakres rzeczowy zadania publicznego proponowanego do realizacji, termin i miejsce realizacji, kalkulację przewidywanych kosztów realizacji, informację o posiadanych zasobach rzeczowych i kadrowych zapewniających wykonanie zadania oraz o planowanej wysokości środków finansowych na realizację zadania pochodzących z innych źródeł, a także deklarację o zamiarze odpłatnego lub nieodpłatnego wykonania zadania.

$\mathrm{W}$ obu przypadkach organ administracji publicznej zobowiązany jest do przeprowadzenia stosownej oceny, co niewątpliwie stanowi przejaw działania społecznego. Powstaje zatem pytanie o kryterium tej oceny, a ściślej — czy jest to działanie celowo racjonalne, czy też wartościowo racjonalne? Wyjściowego materiału w tej kwesti dostarcza sama ustawa, przy czym daje się zauważyć zróżnicowanie regulacji w zależności od trybu inicjacji stosownej procedury.

Jeśli inicjatorem jest zainteresowany podmiot uprawniony, organ administracji publicznej, na mocy art. 12 ust. 2 pkt 1 ustawy, zobowiązany jest przede wszystkim rozpatrzyć celowość realizacji zadania publicznego przez wnioskujący podmiot uprawniony, biorąc pod uwagę stopień, $\mathrm{w}$ jakim wniosek odpowiada priorytetowym zadaniom publicznym określonym w programie współpracy z podmiotami uprawnionymi, zapewnienie wysokiej jakości wykonania danego zadania, środki dostępne na realizację zadań publicznych oraz korzyści wynikające z realizacji zadania publicznego przez uprawniony podmiot.

W wypadku gdy inicjatorem jest organ adminisyracji publicznej, w myśl art. 15 ust. 1 ustawy, ocenia on możliwość realizacji zadania przez podmiot uprawniony, przedstawioną kalkulację kosztów, proponowaną jakość wykonania 
zadania i kwalifikacje osób, przy udziale których uprawniony podmiot będzie realizować zadanie, uwzględnia planowany przez podmiot uprawniony udział środków finansowych własnych tego podmiotu lub środków pochodzących z innych źródeł (dotyczy to tylko wspierania realizacji zadania), planowany przez podmiot uprawniony wkład rzeczowy, osobowy, w tym świadczenia wolontariuszy i pracę społeczną członków, analizę i ocenę realizacji zleconych zadań publicznych w przypadku podmiotów uprawnionych, które w latach poprzednich realizowały zlecone zadania publiczne, biorąc pod uwagę rzetelność i terminowość oraz sposób rozliczenia otrzymanych na ten cel środków.

\section{Konkluzja}

Zastosowane kryteria oceny zdają się wskazywać, że ustawa preferuje działania celowo racjonalne (racjonalność instrumentalną), co nasuwa określone wątpliwości. W demokratyczym państwie prawnym zjawisko administracji publicznej wyróżnia się przecież swoistym celem. Działania społeczne związane z tym zjawiskiem mają być ukierunkowane na realizację szczególnego obiektywu społecznego, szczególnej wartości, a mianowicie - interesu publicznego ${ }^{25}$. Zjawisko administracji publicznej nie może być więc sprowadzane wyłącznie do działań celowo racjonalnych, aczkolwiek nie należy ich lekceważyć. Jednakże to właśnie interes publiczny powinien stanowić ostateczne kryterium zarówno wyboru formy współpracy z podmiotami uprawnionymi, wyboru zadań publicznych, których realizacja miałaby zostać zlecona, w szczególności powierzona podmiotom uprawnionym, jak i wyboru konkretnego podmiotu uprawnionego, nie zaś - często uproszczona - kalkulacja, moda, wygodnictwo, chęć pozbycia się kłopotów czy partykularne interesy.

Należy zatem wyeksponować wartościowo racjonalny charakter działania społecznego w administracji publicznej. Trzeba przy tym pamiętać, że samo zlecenie, czy w szczególności powierzenie, realizacji zadania publicznego podmiotowi uprawnionemu w żaden sposób nie narusza istoty samego zadania publicznego. W pełni należy zgodzić się ze stanowiskiem S. Biernata, który jednoznacznie konstatuje, że

podstawowym kryterium dla uznania danych zadań za zadania publiczne jest okoliczność, iż państwo lub samorząd terytorialny ponoszą w świetle prawa odpowiedzialność za ich zrealizowanie.

25 Szerzej na ten temat zob. A. Pakuła, Interes publiczny jako wartość $w$ administracji publicznej, [w:] Wartości w prawie administracyjnym. V Krakowsko-Wrocławskie Spotkanie Naukowe Administratywistów, red. J. Zimmermann, Warszawa 2015, s. 169 n. 
[...] Odpowiedzialność państwa [i samorządu - A.P.] za wykonanie zadań pozostaje aktualna także w przypadkach upoważnienia do wykonywania tych zadań przez podmioty niepubliczne. Natomiast zmieniają się wówczas zakres i formy tej odpowiedzialności ${ }^{26}$.

Powierzenie wykonania zadania publicznego podmiotowi uprawnionemu nie jest zatem żadną prywatyzacją zadania publicznego, a co najwyżej prywatyzacją proorganizacyjnej formy realizacji nadal publicznego zadania.

\section{The principle of rationality in the phenomenon of public administration in the context of the so-called privatization of public tasks}

\section{Summary}

Public administration is also a social phenomenon. Performing of public tasks is a social activity. They may take the form of purposefully rational and valuably rational activities. Entrusting public tasks to non-public entities should be primarily seen as a valuably rational activity. Fundamental value is the public interest.

Keywords: public administration, social activity, rationality, value, public interest.

${ }^{26}$ S. Biernat, op. cit., s. 29. 